\title{
Bulgarian Export of Consumption Goods and Intermediate Goods Since the Outbreak of the Corona-virus
}

Received: 25.01 .2021

Available online: 28.06.2021

\section{Margarita Ivanova*}

\begin{abstract}
In the context of the dynamic conditions since the beginning of the pandemic, the objective of this article is to explore the changes in the export of Bulgaria. The focus is on two categories: consumption goods and intermediate goods. My approach is based on the examination of the latest available data for trade value. It is combined with a review of relevant publications of international organizations and the academia. The results suggest disruptions in the Bulgarian export of both observed categories since the outbreak of the new virus. Based on early data, the article can be useful to provide initial indication for the variations in export in the first three quarters of 2020. The implications of the outcomes may be limited by the uncertainty of the pandemic and possible unexpected changes in the international trade environment.
\end{abstract}

Keywords: export, consumption goods, intermediate goods, COVID-19

JEL: F69

\section{Introduction}

Lard to foresee changes have had - impact on both the demand and supply side of the economy and transformed the international trade environment. Forecasts for 2020 from the end of 2019 have been modified for various economic aspects, as the agenda of decision makers has been filled with more competing priorities.

In search of objective criteria to evaluate the current situation and potential triggers for faster economic recovery, the purpose of this article is to study the changes in the Bulgarian export of consumption and intermediate goods since the outbreak of the corona-virus.

For the achievement of this objective, this paper has three tasks: first, to review key publications devoted to the impact of the new virus on international trade in order to provide the context; second, to explore the fluctuation of the Bulgarian export of consumption goods; third, to study the dynamics of the Bulgarian export of intermediate goods.

The thesis of the author is that since the outbreak of the COVID-19 there is a disruption in the Bulgarian export of consumption and intermediate goods.

This paper can contribute to gaining first indication about the fluctuations in trade value for the country since the new virus. The significance of the results may be limited by the uncertainty linked to the development of the (health) situation and its influence on international economics.

\footnotetext{
University of National and World Economy - International economic relations and business, Sofia, Bulgaria
} 


\section{Articles}

\section{Discussion of relevant publications}

The impact of COVID-19 has been the main topic of a growing number of publications. A new report has brought together more than thirty international organizations to highlight different economic aspects under the title "How COVID-19 is changing the world" (CCSA, 2020). Three essential remarks from the review of the statistical data are worth mentioning. First, the report shows that it is time of difficult choices as decision makers compete with concurring priorities. Second, the influence on economic and other aspects diverges across different countries and regions. This can be used as a justification for the need of targeted research that focuses on the national level. Third, the solutions to the questions that are imposed currently will not only impact the short term success of the efforts to fight the virus and the negative aspects of the current situation, but could also have a long term impact. Therefore, it is important that objective criteria are used to guide the decision making process.

Covering a wide range of indicators, UNCTAD (2020) reviews the immediate impact of the new virus on the international trade landscape. It highlights that the influence is unprecedented in many aspects and asymmetric in different parts of the world. In the UN briefing "World Economic Situation and Prospects" from September 2020, the collapse in trade is clearly identified, as well as the uneven impact across countries. This is why additional attention is needed on the national level to study the effect of the new virus.

As the forecasts for trade, growth, investments and production output have been modified, the question remains what is the concrete influence on export in the months since the outbreak of the new virus. The difficulties in the trade process have been underlined across countries with different
Bulgarian Export of Consumption Goods and Intermediate Goods Since the Outbreak of the Corona-virus

levels of income in a publication of the WTO, International Chamber of Commerce and Global Alliance for Trade Facilitation (2020).

The academic research begins by publishing different studies. Lestari, Darma, Amalia and Setini (2020) examine international trade in the outbreak of COVID-19 in search of the question whether the digital economy is working. Demir and Javorcik (2020) calculate a reduction in exports of trading nations and discuss risk in international trade transactions and possible solutions to mitigate it. They elaborate on the significance of trade financing in times of uncertainty and the challenges in this respect in the current situation.

Gruszczynski (2020) analyses the consequences of the pandemic for international trade and distinguishes between the short term and long term perspectives. The disruption is highlighted, as well as the effects of the outbreak of the new virus on both the supply and demand side of the global economy (Gruszczynski 2020). Carreño et al (2020) pay attention to the trade-related measures. Topic-specific analyses are produced. Kerr (2020) focuses on agriculture and the implications for international trade relations, while distinguishing between the short and long run implications. Benz, Gonzales and Mourougane (2020) deal with the traveling restrictions and their effect on services-trade costs.

Some publications focus on a particular group of states or region. Éltető (2020) analyses the trade effects of COVID-19 for the Iberian (Spain and Portugal) and Visegrád countries (Poland, the Czech Republic, Slovakia, and Hungary). Attention is given to production chains, in particular the degree of integration in them as a factor for the impact of the current situation. Kassa (2020) reviews trade in Sub-Saharan Africa in the context of the outbreak of COVID-19 around the world. The author discusses the importance of trade 


\section{Articles}

for the countries as a significant share in the national income of their economies compared to other regions, even if they account for a small fraction of international trade as a whole. This is an argument for the need to pay the necessary attention to trade, even if the country is not one of the big nations in exporting around the world. Vidya and Prabheesh (2020) review the data for 15 countries and find a serious decrease in trade interconnectedness, connectivity and density among them after the occurrence of the new virus.

The outbreak of the new virus has influenced international trade, as highlighted above. There will be more data on its impact with the advance of time and new studies can analyze the complexity of the pandemic. Different publications are currently dealing with the overall implications for export and import. Data and analysis are mainly generated on the international level. In this context, it is interesting to study the situation on the national level and in particular in Bulgaria.

\section{Methodology and data use}

This article is based on the review of statistical data from Eurostat and recent publications with reference to international trade in the context of COVID-19. The focus is on the trade value of the Bulgarian export of consumption goods and intermediate goods since the outbreak of the corona-virus. Attention is given to these two categories for several reasons. First, they can be indicative of the influence of COVID-19 on the international trade of Bulgaria. Each group accounts for a substantial part of the Bulgarian export. Second, they allow for a meaningful categorisation of multiple different types of goods. Third, there is still limited information about the subcategories. Different sources provide only partial information for some of them. As time passes, more data will be available and could allow more detailed research. Fourth, this division can be the basis for targeted export measures in the context of the current dynamic situation.

For each of the two categories, the same approach is applied. On the basis of the most recent data available in international trade, two types of comparisons are made. The aim is to provide a better indication of the alterations since the new virus appeared. The first type of comparison examines the data until the third quarter of 2020 and reviews the variations between the past 12 consecutive months. It is particularly interesting whether there will be a change in export immediately after the outbreak of the disease or if there is some time lag. The second type of comparison provides the opportunity to review the current data in the context of the export levels from the previous year. The definitions for export are used as they are introduced by the statistical division of the European commission. The data is in accordance with the requirements of EU legislation, including Regulation (EC) No 471/2009, and displays the calendar year and month in which the goods are exported.

Essential remarks have to be made with reference to the scope and limitations of this publication. The geographic focus is on Bulgaria and its international commerce. The studied data for the export of the country is aggregated and covers the economic relations with all countries in the world. The information depicts the trade value for the two categories of goods to avoid differences in the classification systems and ensure comparability. Due to the complexity of the chosen topic, the assessment of main trading partners and key sectors are outside the scope of the paper.

Beyond the scope of this paper remains the analysis of the factors that could have led 


\section{Articles}

to changes in the export, on the national and international level. The implications (from the fluctuations in trade) for policy making will not be discussed thoroughly either, as more data is needed.

With reference to the time frame, the latest available data is examined. It covers the time until the third quarter of 2020.The trade values include the most recent preliminary data, which may be subject to correction in some cases. Nevertheless, it provides important indication of the fluctuations in the international trade of Bulgaria since the outbreak of the new virus.

\section{Description of the results}

The World Trade Organization (2020) has reviewed data on the importance of trade for more than 190 economies around the world. According to this publication, in world trade, Bulgaria is ranked $62^{\text {nd }}$ in the export of merchandise for 2019 and its share in world total export corresponds to $0.18 \%$. Even if the country is not one of the major players on the international level, the export is still significant for the economy. This is why it is essential to gain first indications about the dynamics in export since the outbreak of the new virus.

Based on the early data available, the results from the study in this paper focus on the variations for consumption goods and
Bulgarian Export of Consumption Goods and Intermediate

Goods Since the Outbreak of the Corona-virus

intermediate goods. The outcomes from the two types of comparisons are presented below.

\section{Fluctuations of the export of consumption goods}

Since the beginning of 2020, there have been dynamic changes. The outbreak of the COVID-19 in many countries, including Bulgaria, has quickly transformed the global context. The first two months could have led to an increase in international trade. However, the virus has led to modifications in forecasts and eventually led to disruptions in many aspects, including trade. The Bulgarian export of consumption goods is not an exception to this general tendency, as indicated by the results described below.

\section{Comparison with previous calendar month}

To gain an understanding of the variations in trade value prior to and after the outbreak of COVID-19, it is beneficial to begin with an examination of the export data for the past twelve months. It covers the time from September 2019 to August 2020. The information, along with the calculated moving average for a period of two months, is presented on the figure below.

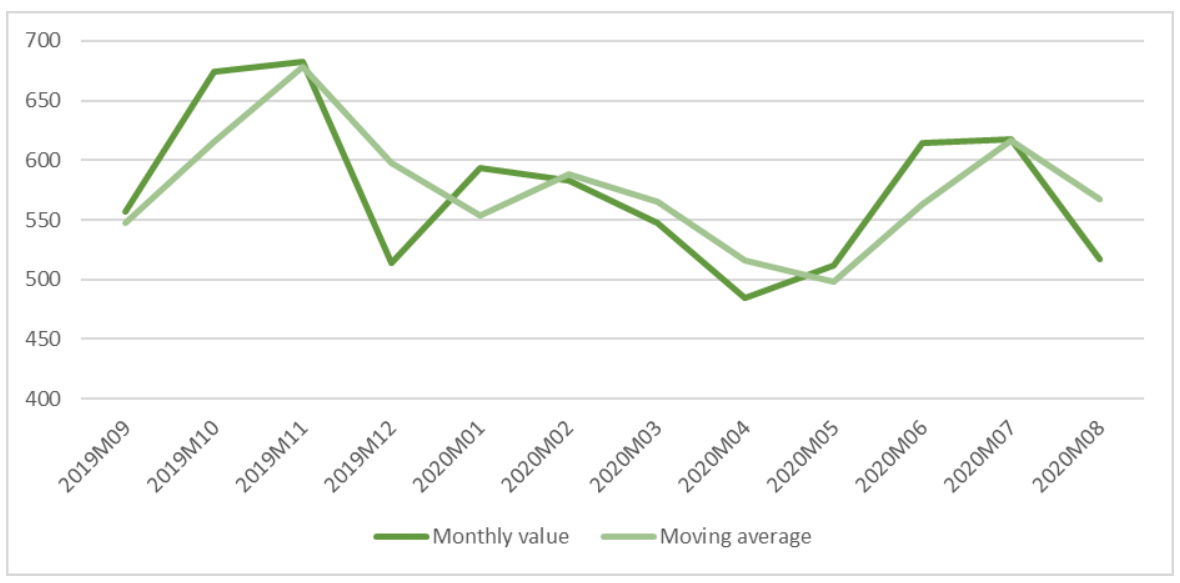

Figure 1: Consumption goods export, trade value in million euro (data source: Eurostat) 


\section{Articles}

The early data allows for several observations to be made, when the information for the consecutive months is compared. There is a downward movement in the exported consumption goods for several consecutive months from January to April 2020. It follows a period of alternating increases and decreases from September 2019 until January 2020. There are important differences in the dynamics of the export level in 2020 and in the previous year. First, the reduction continues for more than two months, which is not the case in 2019, when a month of decrease is followed by an increase in trade. Second, the export reaches a significant fall in 2020 .

The lowest level in the export of consumption goods is in April 2020. It amounts to 484,6 million euro. As the data from the World Health Organization shows, this reduction follows the time when the outbreak of COVID-19 led to changes on the national level in Bulgaria, as well as in the international environment.

The decrease started already in the beginning of the year. From January to February, there has been a modest reduction of $(-1,75 \%)$. From February to March it is $(-6,17 \%)$. The percentage of change has almost doubled for the next month and equals more than $(-11 \%)$, leading to the lowest trade value of export for the studied period. From April to May, there is an increase of $5,57 \%$, but the export still remains at the second lowest point. It is not enough to compensate for the substantial fall that precedes it.

From May to June, the export of consumption goods increased by $20,15 \%$. It reaches 614,7 million euro. Until the next month, the trade value remains almost unchanged: there was an increase of $0,49 \%$.

This upward movement is disrupted in August. It registers the greatest decrease as a percentage change for 2020 and equals
$(-16,30 \%)$. Two aspects should be mentioned. First, this drop is calculated on the basis of one of the highest levels of the Bulgarian export since the beginning of the year. Second, in absolute terms, this fall almost corresponds to the sharpest rise in export for 2020 - from May to June. In other words, this one change erases the positive effects of the increases in export from the previous few months. It leads to one of the lowest levels for the examined period.

The review of the data for the trade value of the Bulgarian export of consumption goods since the beginning of the year reveals a dynamic picture. Since the outbreak of COVID-19, there have been several decreases, when the levels between two consecutive months are compared.

The disruptions in trade flows for consumption goods create unexpected challenges. They basically infringe on the opportunities that stakeholders have had before the pandemic. The consequences can be extensive. More data is needed to analyze them and the implications for the decision making process.

The first step is examining the latest data for the Bulgarian export with emphasis on the time since the new virus. It is useful to position it into the relevant context to help better understand the changes. The next part of this article is dedicated to the topic.

\section{Comparison with the same month from the previous period}

To gain a deeper understanding about Bulgarian export with consumption goods since the new virus appeared, it is useful to collate the values for 2020 with the data for the previous 12 months. The period from September 2019 until August 2020 (denoted as Period 2 on the figure below) is compared with the twelve months from September 2018 until August 2019, marked as Period 1, as it is chronologically first. 


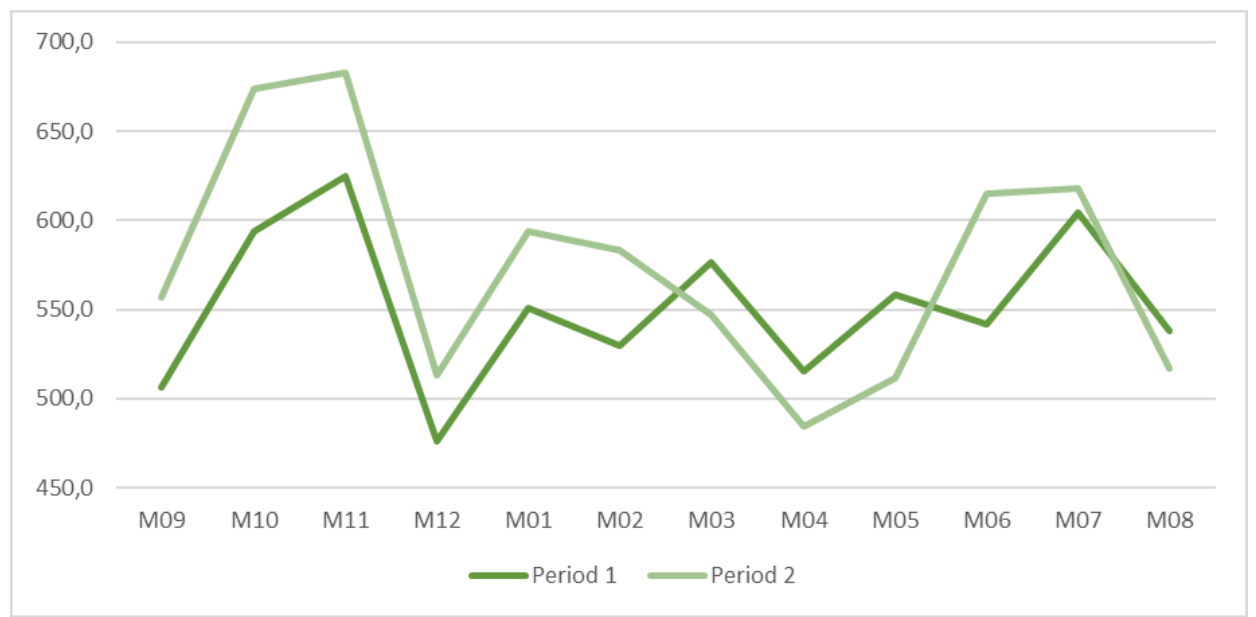

Figure 2: Consumption goods export for 2018-2019 and 2019-2020, trade value in million euro (data source: Eurostat)

A month-by-month comparison, illustrated on the figure above, confirms the dynamic picture for the export since the outbreak of COVID-19. It is beneficial to study the information in more detail.

The export of consumption goods from Bulgaria is linked to the changes that have happened on the international and national level. For the first half of the examined time, from September until February, the export in the second period, which includes the data for the beginning of 2020 , is higher than in the first period. For these months, trade has grown by around $10 \%$ on average.

The development of the major factors in 2019 could have led to an increase in trade in 2020. Due to the abrupt fluctuations in the environment for international trade, this did not happen. The first quarter of 2020 could have recorded much higher values for trade, but this is interrupted in March. For January and February, prior to the force majeure conditions that COVID-19 has brought in Bulgaria, the value of exported consumption goods is higher in 2020 than in 2019. The positive difference amounts to $7,77 \%$ increase for the first month of the year and even a higher rise by $10,06 \%$ for the second.
In March, the export value fell for the first time, in comparison to the same month in the previous period. It records a decrease of $(-5,08 \%)$. It is worth mentioning that in March 2019, the exported consumption goods bring higher value than those in January 2019. This is not the case in 2020, where the level for March is lower than in January.

Since in the end of the first quarter, the export in 2020 fell below the value for 2019, it remained on a lower level for the next two months. For the three consecutive months, the negative difference between 2020 and 2019 increases. This holds true for both the value, measured in million euros, and as a percentage. In April, the export declines by $(-5,94 \%)$ and in May by $(-8,40 \%)$. The lowest points for 2020 are reached.

This downward trend is interrupted in June. A comparison between the exported goods for this month of 2019 and 2020 shows an increase of $13,52 \%$. This is the greatest difference between the values in the studied period of 2020 and is positive. Even if in June 2020 the export of consumption goods increased compared to June 2019, this is not enough to compensate the previous drops, 


\section{Articles}

which will probably be reflected in the yearly data, once they are available.

In July, the level in 2020 is still higher than in 2019 , even if only by $2,15 \%$. August marks another reduction in the level of exported goods. It equals $(-3,85 \%)$. It is worth mentioning that the decline between July and August is steeper in 2020 than in 2019. In 2020 it starts at a higher value and falls to a lower one than the respective months in 2019. The value for August 2020 is one of the lowest for the same year, as it has been elaborated in the previous section.

It is worth mentioning that the fluctuation from January until June in 2019 is not as considerable as in 2020. It is also noted that in 2019, a reduction in export between two consecutive months is followed by a monthly increase. For the first eight months in 2019, there are no two successive falls in the export value.

This is different from the dynamics for consumption goods in 2020 , which is marked by the consequences from the outbreak of COVID-19. The deeper decreases in trade suggest difficulties for the export sector of consumption goods. It implies a divergence between forecasts and achieved export in dynamic economic conditions, when trade values might determine who will stay in business and who not.
After the review of the variations for this group of goods, it is interesting to study the changes in export for the other. The next section of the article deals with this issue.

\section{Dynamics of the intermediate goods export}

To gain a broader understanding about the variations in Bulgarian export, it is essential to review the fluctuations with reference to intermediate goods, as they represent an important part of the trade with other countries.

The abrupt impact of COVID-19 has altered the conditions on the national and international level and the export of intermediate goods has changed, as specified by the results which are presented below.

\section{Comparison with previous calendar month}

Following the same approach as with consumption goods, it is suitable to start with a review of the export for 2020. The latest available information is used to show the dynamics for the past 12 months. The data for the period from September 2019 until August 2020, together with the calculated moving average for a period of two months, is shown on the figure below.

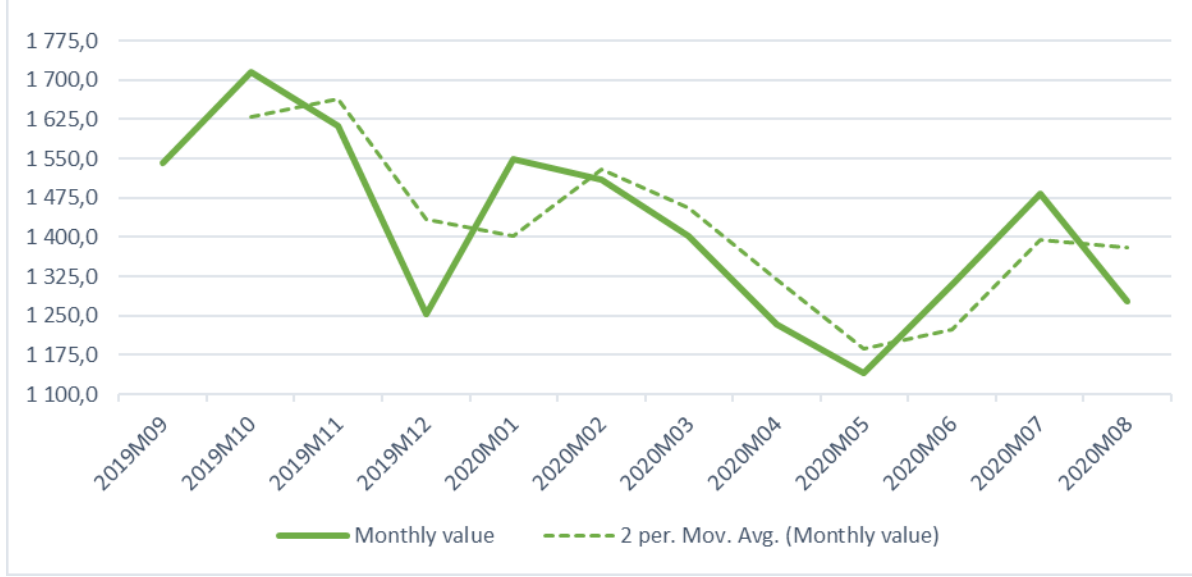

Figure 3: Intermediate goods, trade value in million euro (data source: Eurostat) 


\section{Articles}

The export of intermediate goods is marked by a number of fluctuations. The first five months register reversing upward and downward movements. The increase of value from September until October, leads to the highest level of export, as portrayed above. A two-month decrease is next, which is then followed by a rise that leads to one of the highest levels in the beginning of the new year. When the changes in comparison to the previous calendar months are reviewed, the rest of the studied period can be split into three parts. The first one marks a reduction of the value of the exported intermediate goods for several consecutive months. It starts in January and continues to May 2020. From January to February, there is a decrease of $(-2,58 \%)$. It should be noted that it is measured from one of the highest points for the year, so it still leads to a fall of around $\mathbf{4 0}$ million euro. The decrease has more than doubled from February until March, which corresponds to a change of $(-7,10 \%)$.

This downward movement leads to the low levels during the second quarter of the year. The decrease in the export is steeper in the next month and corresponds to $(-12,12 \%)$. It marks one of the biggest changes (for the studied period), amounting to 170 million euro. The decline continues and the reduction in export from April to May is equal to (-7,48\%).

The second part of 2020 starts after the two months with the lowest values and denotes an increase in trade. It corresponds to the only two consecutive upward movements. As a percentage, the rise from May to June corresponds to $14,67 \%$. Several aspects should be highlighted. This is among the biggest percentage changes for 2020. If the difference is calculated in million euros, it is one of the largest for the same year. However, it is too small to compensate the reduction from the previous months and the export level is still low (compared to the first quarter of
Bulgarian Export of Consumption Goods and Intermediate

Goods Since the Outbreak of the Corona-virus

2020). From June to July, the growth continues by $13,29 \%$. The two consecutive increases give a positive signal for international trade.

However, it is disrupted in August, which denotes the third part. Unlike the previous two months, it records a sharp decrease in trade by $(-13,86 \%)$. The difference corresponds to $(-205,4)$ million euros and is the biggest for 2020. It exceeds the increase from the previous month and leads to the third lowest level for export since the beginning of the year.

The review of the export value of intermediate goods in 2020 has shown some similarities with the fluctuations for consumption goods. For both categories, April and May mark the lowest levels. There is a downward trend from January until April for both. In June and July there are significant increases for both, followed by a sharp decrease in August.

The reduction is associated with challenges not only for the Bulgarian export sector. They can be transmitted along the supply chains to partners in other countries. As the production of many goods may require multiple cross-border movements, the situation becomes more complex. It calls for prompt solutions without compromising longer term objectives. Attention should be directed towards the problems that the export sector of intermediate goods faces. It is beneficial to conduct additional research that explores some of the main factors and implications for stakeholders.

If corrective measures are taken on time, they can turn into a catalyst for recovery. This can support not only those who are affected in Bulgaria, but also their international partners. It is worth mentioning that according to the WTO, the country exports to around 200 partners in different parts of the world. Therefore timely action can have a positive outcome that is far-reaching. 


\section{Articles}

Comparison with the same month from the previous period

To place the latest data for the export of intermediate goods in 2020 in the right context and assess the dynamics since the outbreak of COVID-19, it is appropriate to compare the values with the export in the previous year.
The latest available data is until August 2020, so the monthly results of two time periods are given attention to. Chronologically the first one is from September 2018 until August 2019. The second period is from September 2019 until August 2020. The outcomes are presented in the figure below.

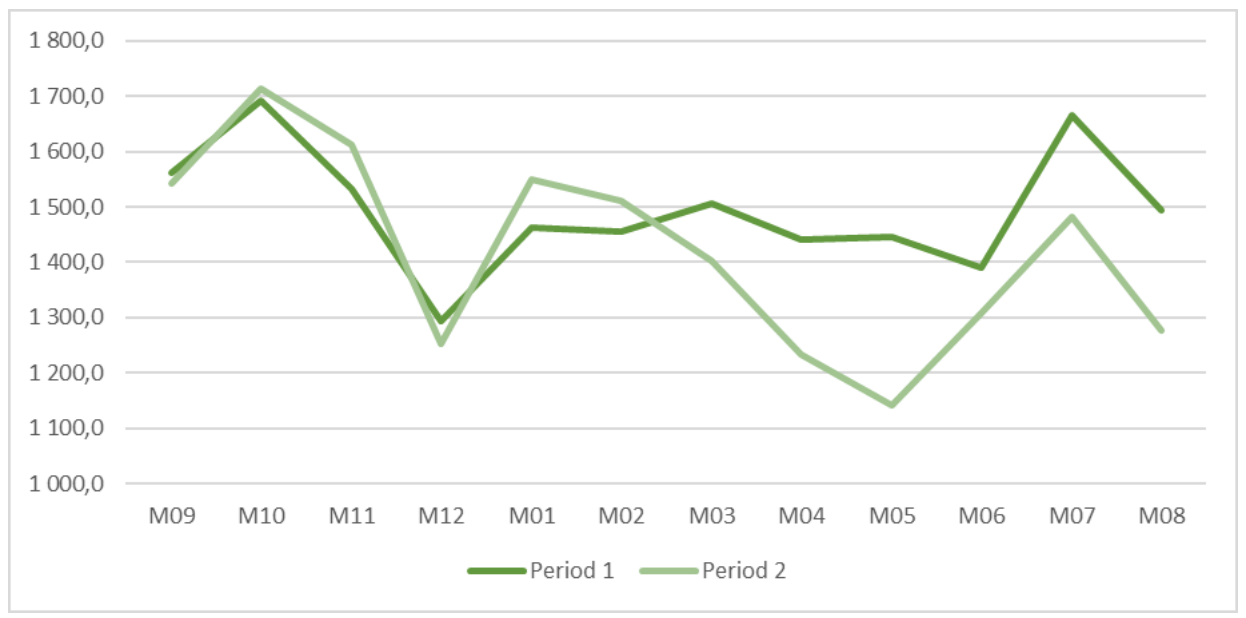

Figure 4: Intermediate goods, trade value in million euro (data source: Eurostat)

The examination of the data highlights that from March until August, the export levels in 2019 remain unachievable for the same month in 2020. Several remarks have to be made. In the first part of the two periods, the monthly values are relatively close to each other. The dissimilarities become bigger from January until August, with a clear turning point. It shifts the positive difference from the beginning of 2020. For January and February, the export in 2020 is higher than in 2019. The increase for the first month of the year corresponds to $6,06 \%$ and for the second the rise in export is $3,72 \%$.

In March, when the outbreak of COVID-19 created force majeure conditions for the first time, the export level changes and the values for 2020 become lower than in 2019. This is valid for the rest of the examined period. It is worth mentioning that the variance between the respective months is altering and requires additional attention.

The difference increases for three consecutive months. A comparison between March 2019 and March 2020 shows a decrease of $(-6,86 \%)$. In April 2019 and 2020 this percentage is more than double and equals $(-14,45 \%)$. In May, the drop goes beyond the $20 \%$ threshold and reaches $(-21,05 \%)$. This is the largest fall for the studied period in this article, which corresponds to $(-304,2)$ million euro.

Such a reduction of the export denotes a challenging signal for international trade. The negative difference between the monthly exports continue in the second and third quarter of the year, as far as the preliminary data suggests.

It is worth noting that in June this change is much lower. The decrease in the export corresponds to $(-5,96 \%)$, when the values 


\section{Articles}

for the same month of 2019 and 2020 are compared. This marks a significant reduction equal to more than eighty million euro. This is one of the smallest alterations with which the value in 2020 is lower than the export in 2019.

A comparison between July 2019 and July 2020 shows that the percentage decrease is almost double. It corresponds to $-11,07 \%$. In August, the difference broadens even more. It marks a reduction of $(-14,60 \%)$.

It is important to note several aspects. First, the variations of the export in 2019 do not reach such a low level as in 2020 . Second, the highest values for 2019 are still not achieved in 2020, as far as the studied period in this paper is concerned. Third, the dissimilarities from January to June in 2019 are not as extensive as for the same months in 2020. For that time in 2019, when the changes in the consecutive months are reviewed, there are almost stable values in the range of close to 1400 million euros to 1500 million euros. In July 2019 a rise followed and reached the peak for the same year. This is not the case in 2020. The fluctuations go deeper and the increase that follows does not lead to the highest levels, as registered in January and February.

The data gives an indication for the difference in export patterns since the outbreak of the new virus. It provides an initial signal for a disruption in trade, which can have diverse consequences. Demir and Javorcik (2020), in a study of the effects of COVID-19 on export and the role of trade finance, have highlighted the potential significance of such a downturn. It threatens the opportunities that have been available prior to the pandemic.

In the context of competing priorities, it is important to devote additional attention to the changes in international trade, which can affect different sectors in Bulgaria and abroad. The unforeseen decrease in the export can put pressure on the production process and
Bulgarian Export of Consumption Goods and Intermediate

Goods Since the Outbreak of the Corona-virus

the supply chain. It could lead to delays or lack of necessary input materials. This can cause distress to the business that may need extra time to adapt - in a period when this is very difficult due to the uncertainty of the current situation during the pandemic. More data is needed to determine the factors that cause the reduction in the export. It is beneficial to explore two possibilities. The first one reviews the situation when intermediate goods are produced in the country and not exported. In this case it is interesting to analyze the reasons - in particular whether they lie with the exporters in Bulgaria or their counterparts abroad. The second evaluates the cases when export goods haven't been prepared yet and this causes the lack of export. Those two scenarios require different action. They highlight the complexity of the situation, which has to be dealt with in the time of the pandemic.

In November 2020 UNCTAD published a paper on the impact of COVID-19 on trade and development, associated with the transition to "a new normal". It raises the question what the role of export will be then. It is up to the countries around the world to determine their answer with reference to their current situation and future goals. For the examined period there has been a reduction in export of both consumption and intermediate goods, as the data for Bulgaria has showed. The answer to the above mentioned question is linked to the efforts taken to alleviate the consequences from the outbreak of the virus, including economic and other aspects. Despite competing priorities, the significance that trade has for the national economy and for international partners should not be underestimated.

\section{Conclusion}

Based on early data for the Bulgarian export since the outbreak of the corona-virus, 


\section{Articles}

this article indicates a disruption for both consumption goods and intermediate goods. The review suggests some similarities in the fluctuations of the export levels for both as well as some differences.

Three common aspects are worth mentioning. First, the examination of the data shows several reductions in export value with reference to the results from the two types of comparisons. Second, the lowest export levels are in April and May, shortly after the outbreak of COVID-19 in Bulgaria. Third, there are positive signals for the development of trade in June and July, followed by a decline in August.

There are some differences among both categories as well as. First, for intermediate goods the latest data indicates that there is a turning point which shifts the trend from the beginning of 2020 and export levels fall below the values for the same month in 2019. This change happens in March 2020 as the corona-virus impacts the usual state of affairs in the country. For the rest of the examined period, the export value for this year remains lower than for the previous one. For consumption goods the picture is dynamic and the "trend" has shifted several times. Second, for consumption goods the lowest export level is in April, while for intermediate goods in May. It could be interpreted as a slightly longer time lag after the outbreak of the COVID-19 in Bulgaria for this category of goods.

The ambiguity of the current situation and the disruptions in the trade with both consumption goods and intermediate goods can trigger significant challenges. The reverberations can be far-reaching, as stakeholders are deprived of opportunities that have been at their disposal before the new virus.

In the context of the uncertainty during the pandemic, the results of this article could provide food for thought for those interested in international economic relations. Their applicability can be limited by possible abrupt changes in the current dynamic situation.

More research is welcome as to the implications for the decision-making process across interested stakeholders. The choices that will be available depend on how long the crisis will continue and how robust it could affect different sectors. The longer it is, the higher the chances that it will lead to more serious transformations for trade. It is particularly interesting what the trade values would be in the last quarter of 2020. More data can contribute towards the objective evaluation of the impact of the new virus on trade.

\section{References}

Benz, S., Gonzales, F., \& Mourougane, A. (2020). The Impact of COVID-19 international travel restrictions on services-trade costs. OECD Trade Policy Papers No. 237

Carreño, I., Dolle, T., Medina, L., \& Brandenburger, M. (2020). The implications of the COVID-19 pandemic on trade. European Journal of Risk Regulation, 11(2), 402-410.

Committee for the Coordination of Statistical Activities, 2020, How COVID-19 is changing the world: a statistical perspective, Volume II September 2020, Publisher: CCSA

Demir, B., \& Javorcik, B. (2020). Trade finance matters: evidence from the COVID-19 crisis. Oxford Review of Economic Policy, 36(Supplement_1), S397-S408.

Éltető, A. (2020). Coronavirus crisis-trade effects for the Iberian and Visegrád countries. Centre for Economic and Regional Studies Institute of World Economics Working Paper Nr. 260 (2020). 1-33. May 2020 ISSN 12155241

European Commission, DG Trade Statistical Guide 2020, Luxembourg: Publications Office of the European Union, ISSN 1977-7949 


\section{Articles}

Eurostat, Statistics about international trade, https://ec.europa.eu/eurostat, last visited December 2020

Gruszczynski, L. (2020). The COVID-19 Pandemic and International Trade: Temporary Turbulence or Paradigm Shift?. European Journal of Risk Regulation, 11(2), 337-342.

Kassa, W. (2020). COVID-19 and Trade in SSA: Impacts and Policy Response. Africa Knowledge In Time Policy Brief, June, 2020 Issue 1, No. 1, Office Of The Chief Economist, Africa Region, World Bank

Kerr, W. A. (2020). The COVID-19 pandemic and agriculture-Short and long run implications for international trade relations. Canadian Journal of Agricultural Economics/ Revue canadienne d'agroeconomie. 2020; 68 (2): 225-229.

Lestari, D., Darma, D. C., Amalia, S. \& Setini, M. (2020). International trade in the COVID-19 outbreak: Is the digital economy working? International Journal of Business and Management, 8(2), 86-92.

Regulation (EC) No 471/2009 of the European Parliament and of the Council of 6 May 2009 on Community statistics relating to external trade with non-member countries and repealing Council Regulation (EC) No 1172/95 UN, World Economic Situation And Prospects: September 2020 Briefing, No. 141 https:// www.un.org/development/desa/dpad/
Bulgarian Export of Consumption Goods and Intermediate

Goods Since the Outbreak of the Corona-virus

publication/world-economic-situation-andprospects-september-2020-briefing-no-141

UNCTAD, 2020, Impact of the COVID-19 pandemic on trade and development: transitioning to a new normal, UNCTAD/ OSG/2020/1, ISBN: 978-92-1-113000-3

Vidya, C. T., \& Prabheesh, K. P. (2020). Implications of COVID-19 pandemic on the global trade networks. Emerging Markets Finance and Trade, 56(10), 2408-2421.

World Health Organization, Coronavirus disease (COVID-19) pandemic,https://www. who.int/emergencies/diseases/novelcoronavirus-2019

World Trade Organization, 2020, Trade Profiles 2020, Publisher: WTO, ISBN: 978-928705038

World Trade Organization, 2020a, World Trade Statistical Review 2020, Publisher: WTO, ISBN: 9287050325

World Trade Organization, International Chamber of Commerce, Global Alliance for Trade Facilitation, The COVID Crisis and Trade Facilitation, Results Of WTO/ICC/ Global Alliance For Trade Facilitation Survey, 2020, Publisher: WTO

World Trade Organization, World Trade Statistical Review 2020, Publisher: WTO, ISBN: 9287050325 